\title{
THE ASSOCIATION OF BIRTHWEIGHT AND FOOD INTAKE WITH THE RISK OF WASTING IN CHILDREN UNDER FIVE IN BOYOLALI, CENTRAL JAVA
}

\author{
Nur Fika Roobiati'), Eti Poncorini Pamungkasari²), \\ Bhisma Murti3) \\ ${ }^{1)}$ Masters Program in Public Health, Universitas Sebelas Maret \\ 2)Faculty of Medicine, Universitas Sebelas Maret
}

\begin{abstract}
Background: Wasting is a priority global public health problem. It is estimated that wasting affects 52 million children (19 million with severe wasting). Each year, approximately 800,000 deaths are attributed to wasting (60\% of which are attributable to severe wasting). This study aimed to examine the association of birth weight and food intake with the risk of wasting in children under five in Boyolali, Central Java.

Subjects and Method: A case control study was carried out in Boyolali, Central Java, from April to May 2018. Twenty five posyandus (integrated health posts) were selected for this study. A random sample of 8 children under five was selected from each posyandu resulting in a total sample of 200 children. The dependent variable was wasting. The independent variables were birth weight and nutritional intake. The data were collected by questionnaire and analyzed by a multiple logistic regression.

Results: The risk of wasting reduced with normal birth weight $(\mathrm{OR}=0.84 ; 95 \%$ $\mathrm{CI}=0.47$ to $1.26 ; \mathrm{p}<0.001)$ and good child nutritional intake $(\mathrm{OR}=0.87 ; 95 \% \mathrm{CI}=$ 0.49 to $1.19 ; \mathrm{p}<0.001)$.

Conclusion: The risk of wasting reduces with normal birth weight and good child nutritional intake.
\end{abstract}

Keywords: wasting, birth weight, child nutritional intake

\section{Correspondence:}

Nur Fika Roobiati. Masters Program in Public Health, Universitas Sebelas Maret, Surakarta, Jl. Ir. Sutami No. 36 A, 57126, Surakarta, Central Java.

Email: nur_fika@ymail.com. Mobile: +6285799504324. 